\title{
Elionurus muticus as an Alternative Source of Citral from Pampa biome, Brazil
}

\author{
Thanise Nogueira Füller ${ }^{1}$, Cedric Bertrand ${ }^{2}$, Annabel Simon ${ }^{2}$, \\ Ingrid Bergman Inchausti de Barros ${ }^{1}$ and José Fernandes Barbosa Neto ${ }^{1 *}$ \\ ${ }^{1}$ Faculdade de Agronomia, Universidade Federal do Rio Grande do Sul, Av. Bento Gonçalves, 7712, Caixa Postal 776, 91501-970, Porto \\ Alegre, Brazil. \\ ${ }^{2}$ Centre de Phytopharmacie, Université de Perpignan, 52 av. Paul Alduy, 66860, Perpignan, France.
}

\begin{abstract}
Elionurus muticus is a grass from Pampa biome and it is an excellent alternative as natural source of citral in southern Brazil. The essential oil has a high citral level $(\mathbf{8 0} \%)$ and presents variability for other important chemical compounds. The present studies indicated its cytotoxic effect against Artemia salina and also suggested its application in the control of pathogenic fungi. $E$. muticus could become an alternative to synthetic fungicides for using in agro-industries and also to screen and develop novel types of selective and natural fungicides.
\end{abstract}

Key words: essential oil, chemical profile, biological activity

\section{INTRODUCTION}

Elionurus muticus is a grass from Pampa biome, Brazil, known as lemongrass. Its essential oil is rich in citral, which is widely used in the aroma, food, and cosmetic industries. The world market for essential oil is increasing at about $11 \%$ per year, where Brazil is among the 15 largest exporters, with $1 \%$ of market share ${ }^{1)}$. One of the essential oils' major compound that is most commercialized is citral, which has a strong citrus odor and is used in perfumery, food, and cosmetics industries. Citral is a mixture of two geometric isomers known as geranial and neral ${ }^{2)}$. Although citral can be obtained synthetically, there is an increasing demand for its natural production.

The mixture of compounds typical in natural products or bioproducts is one of their many advantages, and this may be a major cause of their success on biological tests ${ }^{3)}$. Currently, Cymbopogon citratus is one of the natural sources of citral; however, its production per hectare is low in Brazil $^{4)}$. Elionurus muticus is an aromatic grass that is characterized by the presence of citral as major compound of its essential oil ${ }^{5)}$. E. muticus belongs to the Poaceae family and is known as lemongrass. It is native from Pampa biome, in Rio Grande do Sul, Brazil. The essential oil yield of both species is similar ${ }^{6)}$. In addition, as E. muticus occurs in abundance in Pampa biome, it demands little or no management, especially when compared with $C$. citratus. All these reasons make $E$. muticus a potential natural source for citral production in Brazil.

Another reason for exploitation of bioproducts is their function as new biopesticide agents in plant protection and postharvest protectant. Post-harvest diseases render heavy losses to perishables during transit and storage. Higher water content, nutrient composition, and $\mathrm{pH}$ of most perishables make them capable of supporting the growth of a number of microorganisms. Fruits, due to their low pH, are spoiled primarily by fungi, which in addition to causing rot, may also contaminate fruits by producing mycotoxins. Worldwide post-harvest loss of perishables due to fungi is between $10 \%$ and $50 \%$. Essential oils have been proven to be active against several pathogenic fungi ${ }^{7-9)}$.

Among post-harvest fungal pathogens, Botrytis allii, $B$. cinerea, and Penicillium expansum are three of the most commons causal agents of diseases. B. allii species are very important in onion crop; it causes the disease known as neck rot during storage, causing losses of more than $60 \%$ in production in a few years. Infected onions are often asymptomatic and may develop the disease in transit or during storage, resulting in poor quality, mainly affecting onions for export ${ }^{10,11)}$. B. cinerea has extensive worldwide distribution; this fungus causes the so-called gray mold and can infect almost all plants and plant parts. In addition, it can cause latent infections that damage fruits before ripen$\operatorname{ing}^{12)}$. B. cinerea produces a range of enzymes, toxins, and other low molecular weight compounds that degrade cell

\footnotetext{
*Correspondence to: José Fernandes Barbosa Neto, Faculdade de Agronomia, Universidade Federal do Rio Grande do Sul, Av. Bento Gonçalves, 7712, Caixa Postal 776, 91501-970, Porto Alegre, Brazil.

E-mail: jfbn@ufrgs.br

Accepted July 18, 2014 (received for review December 25, 2013)

Journal of Oleo Science ISSN 1345-8957 print / ISSN 1347-3352 online

http://www.jstage.jst.go.jp/browse/jos/ http://mc.manusriptcentral.com/jjocs
} 


\section{T. N. Füller, C. Bertrand, A. Simon et al.}

wall. Evidence suggests that the pathogen induces the host to trigger the process of programmed cell death as a highlighted strategy ${ }^{13)}$. P. expansum affects most fruits and vegetables. In some fruits, such as citrus, infections can start in the field, but are essentially post-harvest diseases and can often cause up to $90 \%$ decomposition in transit, storage, and marketing ${ }^{10)}$. Penicillium enters the tissues through wounds. However, it can also spread from infected fruits to healthy skin upon contact, even if the skin does not have open wound. In addition to the losses caused by rotting of fruits and vegetables, Penicillium also produces several mycotoxins that contaminate products made from healthy fruits and rotten parts ${ }^{10}$. For instance, almost $100 \%$ of $P$. expansum strains produces patulin as mico$\operatorname{toxin}^{14)}$.

In addition to fungicidal activity, several essential oils are known to show cytotoxic activities ${ }^{15,16)}$. One of the most common tests to determine the toxicity of various plant extracts is the Artemia salina's lethality assay. A. salina has purine metabolism similar to mammalian cells and has been demonstrated to have a good correlation with antitumor activity ${ }^{17,18)}$.

The essential oil of $E$. muticus shows high potential as a bioproduct, but despite the demand, few studies have been conducted on this species ${ }^{5,6,19-22)}$. Thus, the aim of this study was to characterize chemically the essential oil of $E$. muticus collected in southern Brazil to compare the profile with $C$. citratus and to verify its biological activity.

\section{EXPERIMENTAL}

Plants were collected in São Borja, Brazil (S28 $47^{\prime} 25.9^{\prime \prime}$ । $\left.\mathrm{W} 56^{\circ} 05^{\prime} 52.2^{\prime \prime}\right)$, and assembled and catalogued in the Herbário ICN from Departamento de Botânica/UFRGS (152282), Brazil. The collected plants were transplanted to pots containing $5 \mathrm{~L}$ of substrate and maintained in the greenhouse of the Departamento de Horticultura of the Faculdade de Agronomia/UFRGS. Plants were collected in October 2010 and all the work was carried out in 2 years (2010-2012).

Fresh leaves were harvested from 18 individual plants and kept in the freezer for further extraction. The essential oil was extracted through hydrodistillation in a Clevenger apparatus. The aqueous phase was separated with anhydrous magnesium sulfate. The extracted oil was stored in glass containers protected from light at $-20^{\circ} \mathrm{C}$. Plant fresh weight vary from each plant in the range of 20 to $102 \mathrm{~g}$. Essential oil yield was estimated according to Santos et al. $(2004)^{23)}$.

Essential oil constituents were analyzed for each plant using gas chromatography with a Thermo Scientific Focus GC with flame ionization detector (FID) using DB-5 capillary column $(30 \mathrm{~m} \times 0.25 \mathrm{~mm} \times 0.25 \mu \mathrm{m})$ with helium as carrier gas (flow $1.0 \mathrm{~mL} / \mathrm{min}$ ) with an injection volume of 1 $\mu \mathrm{L}$ (2\% solution in heptane); the initial pressure was 1.91 $\mathrm{Pa}$. Column temperature was programmed as follows: $80^{\circ} \mathrm{C}$ for $5 \mathrm{~min}, 80^{\circ} \mathrm{C}$ to $170^{\circ} \mathrm{C}\left(2^{\circ} \mathrm{C} / \mathrm{min}\right), 170^{\circ} \mathrm{C}$ to $260^{\circ} \mathrm{C}\left(10^{\circ} \mathrm{C} /\right.$ $\mathrm{min}$ ), and the end was $260^{\circ} \mathrm{C}$ for $2 \mathrm{~min}$. The injector temperature was $250^{\circ} \mathrm{C}$, with injection in "splitless" mode. The analyses lasted $61 \mathrm{~min}$. Samples were analyzed in three replicates each.

The essential oils were also analyzed and identified using mass spectrometry in chromatography coupled to mass selective detector DSQ II with the same conditions described previously. The condition has an impact energy of $70 \mathrm{eV}$. Chemical constituents were identified through studies of mass spectra, supplemented by computerized comparison of library equipment and the literature.

A series of alkanes (C9 to C30) was injected under the same conditions of the samples. The linear regression analysis of retention time corresponding to the number of carbons in each alkane was performed to obtain the Kovats index (KI), together with the retention time of each compound. KIs were compared with the literature data ${ }^{24,25)}$. Each sample was analyzed three times. Mean and standard error were estimated for each compound detected in the analysis. The means were further compared with a commercial Cymbopogon citratus oil sample with a t-test using R software ${ }^{26)}$.

The experiments designed to test the biological activity of the essential oil of $E$. muticus were also performed with the essential oil of Cymbopogon citratus and then compared with the pure compound citral. Citral was obtained from Alfa Aesar (Lot 10168526), and the essential oil of $C$. citratus was obtained from BIO EEC Madagascar (Lot 564N001-Ech. 839).

Fungal activity experiments tested strains of Penicillium expansum (03/02/10 - IP 1350.82), Botrytis cinerea (22/02/20 - IP 1854.89), and Botrytis allii(02/03/10 - IP 1405.82), all obtained from Institut Pasteur (Paris, France). The activity was determined by contact and fumigation. The strains were cultivated for 7 days in bacteriologicalmalt agar medium (BM) consisting of $2 \%$ malt agar and $2 \%$ bacteriological agar. Three replicates were evaluated for each strain, and they were maintained at $23^{\circ} \mathrm{C}$. After cultivation, the strains were collected with the aid of a sterile pipette to obtain discs with $0.5 \mathrm{~cm}$ of diameter, and were then spread on a Petri dish containing medium BM for the tests.

The fungicidal activity by contact was determined using diffusion in agar ${ }^{27)}$ consisting of an in vitro test where the strain was submitted to a contact with the essential oil. The strains were cultured for 7 days on BM and subsequently maintained at $23^{\circ} \mathrm{C}$. After culture period, five plates with 12 wells were filled with $2 \mathrm{~mL}$ of medium BM and essential oil or citral. Five concentrations were tested: $0 \%, 0.01 \%, 0.015 \%, 0.02 \%$, and $0.03 \%$. Each plate corre- 
sponded to a concentration.

The fumigation activity consisted of an in vitro test where the strains were submitted to the essential oil vapor. The strains were cultured for seven days on BM medium and subsequently maintained at $23^{\circ} \mathrm{C}$. After seven days of culture, strains were transferred into a new plate containing MB medium and the essential oil was added to a paper pulp with a diameter of $8 \mathrm{~mm}$, fixed on the lid of the plate. Each plate contained three strains for evaluation, and there were three replicates for each treatment. Treatments were evaluated at seven doses: $0,1,2,4,6,8$, and 10 $\mu \mathrm{L} . \mathrm{mL}^{-1}$ air; each plate corresponded to a dose.

The extent of fungal mycelium was measured at $24 \mathrm{~h}$ interval until the mycelium of the negative control reached the side of the plate on the 4th day. Results were submitted to analysis of variance, considering the type of essential oil, doses, application mode (contact and fumigation), and species of fungus as factors. The percentage of minimum inhibitory concentration $\left(\mathrm{MIC}_{50}\right)$ was estimated using simple linear or quadratic regression adjusting the dependent variable to 50 and estimating the independent variable using the fitted model. All statistical analyses were performed with $\mathrm{R}^{26)}$.

Artemia's cysts were hatched in filtered seawater collected in Canet, France. To the cysts' eclosion, seawater was added to approximately $80 \%$ of a Petri dish. Half of the plate remained in the dark, and the opposite side with light was maintained for $48 \mathrm{~h}$. Because they are phototropic, the artemias migrated toward the light side.

After eclosion ( $48 \mathrm{~h})$, the solutions were prepared in acrylic tubes in seven different concentrations of essential oil or citral: $1,2.5,5,7.5,10,20$, and $30 \mu \mathrm{g} \cdot \mathrm{mL}^{-1}$. The solutions were diluted in dimethyl sulfoxide(DMSO) $1 \%$, and 5 $\mathrm{mL}$ of seawater was added in each tube. Control treatment consisted of seawater with DMSO 1\%. As positive control, potassium dichromate was used in the same concentrations tested.

With a pipette, 10 artemias were counted for each tube. Each concentration was tested in triplicates. The tubes were left in contact with the light and, after $24 \mathrm{~h}$, were analyzed. The larvae were considered dead when they did not show normal movement during $10 \mathrm{~s}$ observation. Toxicity was determined using a $50 \%$ lethal dose $\mathrm{LC}_{50}$, which was estimated according to the Reed-Muench $(1938)^{28)}$ method and the percentage of larvae mortality. The larvae mortality data were submitted to analysis of variance, and the means were separated using Tukey's test $(\alpha=0.05)$ and $R^{26)}$.

\section{RESULTS AND DISCUSSION}

Elionurus muticus showed an essential oil yield of 0.7 $\pm 0.14 \%$, which is high compared with values obtained by other authors, that reached values around $0.1 \%$ to $0.5 \%$ (considering other species from the genus Elionurus) ${ }^{5,6,29)}$. It is also high, considering that the essential oil was extracted from a wild species and during the winter season, which usually causes a decrease in essential oil yield ${ }^{5)}$. The yield per plant ranged from $0.13 \%$ to $1.26 \%$, the ones with higher plant fresh weight with the most productive.

Chemical profile showed the predominance of monoterpenes, representing about $90 \%$ of the essential oil, and it also revealed the presence of some sesquiterpenes for $E$. muticus and C. citratus (Table 1). The essential oils of both species exhibit the typical characteristics of oils rich in monoterpenes as clear coloration, low viscosity, and high volatility. Because of these features, the essential oils rich in monoterpenes are widely used as flavorings and repellents. In addition, being small molecules, it easily penetrates tissues and cells.

The major compound for both species is citral (neral + geranial), corresponding to approximately $80 \%$ of the essential oil. Citral is also the major compound of the essential oil from Elionurus species collected in Argentina, Uruguay, and Zimbabwe ${ }^{6,7)}$. Silou et al. $(2006)^{30)}$, analyzing the composition of the essential oil from leaves of $E$. hensii from Congo, observed the predominance of the compounds cis- and trans-p-mint-2.8(9)-dien-1-ol, cis- and trans- $p$ mint-1 (7) 8-dien-2-ol, 2-undecanone and 2-tridecanone. Still in Africa, Mevy et al. (2002) ${ }^{29)}$ obtained the following major compounds from the aerial parts of E. elegans: campherenone $(43.0 \%)$, caryophyllene oxide $(4.9 \%)$, and bisabolone $(4.9 \%)$. In Brazil, the essential oil composition varies according to region. In the central region, the presence of camphene (11.5\%), (E)-caryophyllene (17.9\%), and spathulenol(18.6\%) as major components was verified $^{19)}$. In southern Brazil, especially in the border regions with Argentina and Uruguay, geranial and neral are present as major constituents of the essential oil ${ }^{20)}$.

Usually, species from the genus Cymbopogon are used in the perfumery and pharmaceutical industries because of its citral content. However, in Brazilian climate conditions, its production per hectare is low, mostly because of its lower resistance to cold, slower growth, and susceptibility to leaf rust ${ }^{4)}$. On the other hand, E. muticus is an excellent alternative as natural source of citral because it is native to Brazil, being adapted to the environment and, therefore, requiring little or no field management. E. muticus develops in poor soils, improving degraded areas ${ }^{4)}$. In addition, E. muticus essential oil has higher diversity of compounds that can be present in low concentration (Table 1), such as limonene, which has an important commercial demand.

Analysis of fungicidal activity indicated that citral and essential oil from E. muticus and C. citratus are effective against the fungi tested, because all treatments are found to inhibit the growth of all fungi tested in a dose-dependent manner (Table 2). In comparing contact and fumigation tests, fumigation was observed to be more effective in in- 
Table 1 Retention index (RI) in a DB-5 column and percentage of the compound in the essential oil of Elionurus muticus and Cymbopogon citratus.

\begin{tabular}{lcccc}
\hline \multirow{2}{*}{ Compound } & \multicolumn{2}{c}{ E. muticus } & \multicolumn{2}{c}{ C. citratus } \\
\cline { 2 - 5 } & RI & $\%$ & RI & $\%$ \\
\hline Alpha-pinene & 939 & $2.73 \pm 0.902^{* *}$ & - & - \\
Myrcene & 989 & $2.69 \pm 0.741^{* *}$ & 989 & 9.81 \\
Limonene & 1027 & $0.54 \pm 0.126^{* *}$ & - & - \\
Eucaliptol & 1032 & $0.44 \pm 0.092^{*}$ & 1034 & 0.37 \\
Ocimene-cis-beta & 1041 & $0.40 \pm 0.097$ & 1044 & 0.55 \\
Linanool & 1101 & $1.98 \pm 0.131^{* *}$ & 1099 & 1.50 \\
Cis-cis-photocitral & 1162 & $0.59 \pm 0.085$ & 1162 & 0.11 \\
Trans-trans-photocitral & 1181 & $1.14 \pm 0.120$ & 1181 & 0.20 \\
Citronellal & 1228 & $0.14 \pm 0.027$ & 1228 & 0.27 \\
Neral & 1239 & $31.54 \pm 0.856^{* *}$ & 1244 & 32.22 \\
Geraniol & 1252 & $0.80 \pm 0.395^{* *}$ & 1253 & 4.34 \\
Geranial & 1275 & $47.33 \pm 1.889$ & 1267 & 42.55 \\
Bornyl acetate & 1284 & $0.17 \pm 0.064^{*}$ & 1279 & - \\
Alpha-ylangene & 1365 & $0.02 \pm 0.025$ & - & - \\
Geranyl acetate & 1377 & $0.74 \pm 0.194^{* *}$ & 1383 & 1.54 \\
Beta-caryophyllene & 1413 & $0.34 \pm 0.118^{* *}$ & - & - \\
Ar-curcumene & 1477 & $0.27 \pm 0.130^{*}$ & - & - \\
Zingiberene & 1491 & $0.15 \pm 0.075^{*}$ & - & - \\
Elemol & 1532 & $0.04 \pm 0.025$ & - & - \\
Trans-nerolidol & 1559 & $0.28 \pm 0.251$ & - & - \\
Cariophilene oxide & 1571 & $0.12 \pm 0.041^{* *}$ & - & - \\
10-epi-gamma-Eudesmol & 1602 & $0.02 \pm 0.010^{*}$ & - & - \\
Isospathulenol & 1621 & $0.01 \pm 0.006^{*}$ & - & - \\
\hline
\end{tabular}

*, ** Mean significantly different from Cymbopogon citratus value at $5 \%$ and $1 \%$ of probability, respectively, according to $t$ test.

hibiting mycelium growth. When oil is added in the culture medium, the absorption of the essential oil is slower, depending on the fungus growth and substrate consumption $^{31)}$. On the other hand, the higher toxicity by fumigant treatment occurs more rapidly because of the direct effect of the essential oil vapors on the fungal mycelia. Some investigators reported that the lipophilic nature of essential oils render them more absorbable by the fungal mycelia than by agar due to the highly lipophilic nature of the fungal mycelia and the high water content of the agar media $^{32,33}$.

Among all the essential oils tested, volatile and contact phases of citral caused the largest inhibition of mycelium growth for all fungi (Table 2). These results could be comparable with MIC values of the most frequently used synthetic fungicides ${ }^{34)}$. According to literature, the MIC values obtained in this work indicate a notable fungicidal effect for all treatments. For example, literature shows a $\mathrm{MIC}_{50}$ range from 1.6 to $500 \mu \mathrm{g} \cdot \mathrm{mL}^{-1}$ in contact phase ${ }^{9,34-38)}$ and a range of 0.08 to $300 \mu \mathrm{g} \cdot \mathrm{mL}^{-1}$ air in volatile phase ${ }^{39-41)}$ for the fungi tested.

When the treatment was applied by contact, the pure compound citral had higher inhibition of mycelium of Botrytis allii, inhibiting $50 \%$ of the mycelial growth at a concentration of $2.15 \mu \mathrm{g} \cdot \mathrm{mL}^{-1}$ (Table 2). Against this fungus, $C$. citratus essential oil showed the poorest response, with an average of $11.38 \%$ inhibition, not reaching $\mathrm{MIC}_{50}$ at any concentration tested (Table 2). Fumigation test was more effective for $B$. allii inhibition. All essential oil tested produced similar average mycelium inhibition. Minimum inhibitory concentration $\left(\mathrm{MIC}_{50}\right)$ was $3.48 \mu \mathrm{g} . \mathrm{mL}^{-1}$ air for citral, whereas for the essential oil of E. muticus, 
Table 2 Average percentage of mycelium growth inhibition and minimum inhibitory concentration $\left(\mathrm{MIC}_{50}\right)$ for Elionurus muticus and Cymbopogon citratus essential oil and citral by contact $\left(\mu \mathrm{g} \cdot \mathrm{mL}^{-1}\right)$ and fumigation $\left(\mu \mathrm{g} \cdot \mathrm{mL}^{-1}\right.$ air) against the fungi Botrytis allii, $B$. cinerea and Penicillium expansum.

\begin{tabular}{|c|c|c|c|c|c|c|c|c|c|c|c|}
\hline \multirow{2}{*}{ Treatment } & \multicolumn{8}{|c|}{ Inhibition (\%) } & \multicolumn{3}{|c|}{$\mathrm{MIC}_{50}$} \\
\hline & \multicolumn{2}{|l|}{ E } & \multicolumn{2}{|l|}{$\mathrm{C}$} & \multicolumn{2}{|c|}{ Citral } & \multicolumn{2}{|c|}{ Mean } & $\mathrm{E}$ & $\mathrm{C}$ & Citral \\
\hline \multicolumn{12}{|c|}{ B. allii } \\
\hline Contact & 33.33 & $b^{*}$ & 11.38 & $\mathrm{c}$ & 66.67 & a & 38.12 & $\mathrm{D}^{* *}$ & 3.07 & - & 2.15 \\
\hline Fumigation & 54.81 & $\mathrm{a}$ & 46.63 & $a b$ & 59.45 & $\mathrm{a}$ & 53.77 & C & 3.96 & 4.94 & 3.48 \\
\hline \multicolumn{12}{|c|}{ B. cinerea } \\
\hline Contact & 33.33 & $\mathrm{~b}$ & 66.67 & $\mathrm{a}$ & 66.67 & $\mathrm{a}$ & 55.56 & $\mathrm{C}$ & 3.07 & 2.32 & 2.15 \\
\hline Fumigation & 83.57 & $\mathrm{a}$ & 82.24 & $\mathrm{a}$ & 85.71 & $\mathrm{a}$ & 83.84 & A & 0.75 & 0.68 & 0.46 \\
\hline \multicolumn{12}{|c|}{ P. expansum } \\
\hline Contact & 44.51 & $\mathrm{~b}$ & 67.41 & $\mathrm{a}$ & 71.68 & $\mathrm{a}$ & 61.51 & $\mathrm{C}$ & 1.71 & 3.59 & 1.66 \\
\hline Fumigation & 67.70 & $\mathrm{a}$ & 69.10 & $\mathrm{a}$ & 77.71 & $\mathrm{a}$ & 71.61 & B & 2.76 & 2.57 & 1.21 \\
\hline
\end{tabular}

* Means followed by the same lower case letter in each fungus are not statistically different according to Tukey's test $(\alpha=0.05)$.

** Means followed by the same upper case letter are not statistically different according to Tukey's test ( $\alpha$ $=0.05)$.

$\mathrm{MIC}_{50}$ was reached at $3.96 \mu \mathrm{g} . \mathrm{mL}^{-1}$ air (Table 2). All treatments on volatile phase exhibited total control of $B$. allii $(100 \%)$ at $8 \mu \mathrm{g} \cdot \mathrm{mL}^{-1}$ air.

Botrytis cinerea also responded to the treatments. The pure compound citral and the essential oil of $C$. citratus showed higher activity when used in contact, $\mathrm{MIC}_{50}$ was reached at a concentration of $2.15 \mu \mathrm{g} \cdot \mathrm{mL}^{-1}$ and $2.32 \mu \mathrm{g} \cdot \mathrm{mL}^{-1}$ for citral and C. citratus, respectively. For the essential oil of $E$. muticus, a concentration of $3.07 \mu \mathrm{g} . \mathrm{mL}^{-1}$ was necessary (Table 2). The fumigation test for $B$. cinerea also showed more efficiency than contact test, revealing inhibition of $50 \%$ of mycelial growth at $0.46 \mu \mathrm{g} . \mathrm{mL}^{-1}$ air for citral, followed by the essential oil of $C$. citratus that inhibits growth at $0.68 \mu \mathrm{g} \cdot \mathrm{mL}^{-1}$ air, and the essential oil of $E$. muticus at $0.75 \mu \mathrm{g} \cdot \mathrm{mL}^{-1}$ air (Table 2 ).

Results for $P$. expansum were also similar for all oil treatments, except for E. muticus oil used in contact, which showed a lower mycelium inhibition, $44.51 \%$ (Table 2 ). For the contact treatment, citral inhibits $50 \%$ of the mycelium growth at a concentration of $1.66 \mu \mathrm{L} \cdot \mathrm{mg}^{-1}$ (Table 2 ). With the fumigation test, citral was highly toxic with $1.21 \mu \mathrm{L} . \mathrm{mg}^{-1}$ air. Total inhibition was achieved at $2 \mu \mathrm{L} . \mathrm{mg}^{-1}$ air for citral, $4 \mu \mathrm{L} \cdot \mathrm{mg}^{-1}$ air for $C$. citrates, and $6 \mu \mathrm{L} \cdot \mathrm{mg}^{-1}$ air for $E$. muticus, evidencing a strong fungicidal effect.

The activity of essential oil is related to its chemical composition, structural configuration of its compounds, and its functional groups, with synergistic antagonist interactions of its chemical components ${ }^{9}$. Essential oils abundant in citral are well known for its antibacterial and fungicidal activities ${ }^{9,21,22,42)}$. Ben-Yehoshua et al. $(1992)^{31)}$ observed a correlation between the reduction of the con- centration of citral in lemon and the increase of susceptibility to infection by P. digitatum. E. muticus essential oil was proven to be efficient against Candida spp., Candida albicans, Saccharomyces cerevisiae, and some bacteria ${ }^{21,22,29)}$. Studies on $C$. citratus essential oil also showed fungicidal activities against Colletotrichum coccodes, B. cinerea, Cladosporium herbarum, Rhizopus stolonifer, Aspergillus niger, A. ochraceus, and P. expansum ${ }^{9,42,44)}$.

The results show that in general, citral was more efficient as or similar to a fungicide compared with the essential oils. Linde et al. $(2010)^{45)}$ found a higher fungicidal activity of the pure compound in comparison with essential oils whose major component was citral. This can be explained by the complexity of compounds of essential oils that, even with citral as the major compound, exhibit small amounts of other compounds that can provide an association between its effects and the presence of citral in the essential oil. Working with Orthosiphon stamineus essential oil, against B. cinerea, Hossain et al. $(2008)^{46}$ attributed the fungicidal effect to the essential oil's major components, $\beta$-caryophyllene, caryophyllene oxide, $\alpha$-humulene, $\beta$-pinene, limonene, and $\beta$-elemene, which were found in $E$. muticus essential oil in minor concentration.

Few studies have focused on the mechanism by which essential oils inhibit microorganisms. Generally, the essential oils are known to be lipophilic, and thus, pass through the cell wall and cell membrane, affecting the structure of different layers of polysaccharides, fatty acids, and phospholipids and causing its permeabilization. Therefore, the effect of cytotoxicity is believed to include damage to the membrane ${ }^{47)}$. 
Table 3 Mortality and lethal dose $\left(\mathrm{LD}_{50}\right)$ of essential oil of Elionurus muticus (EM). Cymbopogon citratus (CC) and citral in Artemia salina.

\begin{tabular}{lcc}
\hline \multicolumn{1}{c}{ Treatment } & Mortality $(\%)$ & $\mathrm{LD}_{50}\left(\mu \mathrm{g} \cdot \mathrm{mL}^{-1}\right)$ \\
\hline Control & $0.00 \mathrm{~b} *$ & \\
Elionurus & $51.43 \mathrm{a}$ & 7.64 \\
Cymbopogon & $21.43 \mathrm{ab}$ & 20.00 \\
Citral & $50.00 \mathrm{a}$ & 7.96 \\
\hline
\end{tabular}

* Means followed by the same letter are not statistically different according to Tukey's test $(\alpha=0.05)$.

The toxic activity of citral may be related to its conformation ${ }^{48)}$. Being a class of aldehydes $\alpha, \beta$-unsaturated, the position of carbonyl group and the carbons $\alpha$ and $\beta$ generates a conjunction between them, which makes the $\beta$ carbon more positively polarized and consequently, more reactive with nucleophiles. The toxic effect of these aldehydes is based on their ability to act as direct-alkylating agents capable of covalent binding to cellular nucleophilic groups, modifying cellular processes and being potentially toxic to pathogens. Thus, the fungal difference in susceptibility to the treatments may be related to the content of protein in the fungal cell wall.

The test with Artemia salina revealed that the essential oils of both species (E. muticus and C. citratus) and citral are highly cytotoxic (Table 3 ). However, the essential oil of C. citratus showed an intermediate behavior, being similar to the control(no treatment). This result suggests that the toxic effect is mainly due to the high content of citral found in the essential oil. Several studies have shown the toxic activity of citral in various organisms and cells $\left.{ }^{49}, 50\right)$. The lethality of Artemia salina may be used as an indicator of antitumor compound and insecticide activity ${ }^{51)}$. These authors proposed a classification based on $\mathrm{LD}_{50}$, where values between $1(1 \mathrm{mg} / \mathrm{mL})$ and $40 \mathrm{ppm}(40 \mathrm{mg} / \mathrm{mL})$ characterize an antitumor compound and values below $1 \mathrm{ppm}$ characterize an insecticide product. Consequently, the oils studied in the present work could be exploited for antitumoral activity but not insecticide activity (Table 3 ) .

\section{CONCLUSIONS}

Elionurus muticus is an excellent alternative as natural source of citral in southern Brazil. Its essential oil is rich in citral and presents variability for other important chemical compounds. The present study indicated its cytotoxic effect against $A$. salina and suggested its application in the control of pathogenic fungi. E. muticus could become an alternative to synthetic fungicides for use in agro-industries, also for use in screening and developing novel types of selective and natural fungicides.

\section{ACKNOWLEDGMENTS}

The authors acknowledge Coordenação de Aperfeiçoamento de Pessoal de Ensino Superior (Capes) and Conselho Nacional de Desenvolvimento Científico e Tecnológico (CNPq) for their financial support, and Dr. Fernanda Bered, Dr. Magnólia Silva, and Dr. Geraldo Soares for their valuable suggestions.

\section{References}

1) COMTRADE-United Nations Commodity Trade Statistics Database. Essential oils, perfume and flavour materials < http://comtrade.un.org/> Accessed on 14 April 2013 (2013).

2) Heydorn, S.; Menne, T.; Andersen, K. E.; Bruze, M; Svedman, C.; White; I. R.; Basketter, D. A. Citral, a fragrance allergen and irritant. Contact Dermatitis 49, 32-36 (2003).

3) Dubey, N. K.; Srivastava, B.; Kumar, A. Current status of botanicals in storage pest management. J. Biopestic. 1, 182-186 (2008).

4) Castro, L. O.; Ramos, R. L. D. Principais gramíneas produtoras de óleos essenciais: Cymbopogon citratus (DC) Stapf., capim-cidró, Cymbopogon martinii (Rox.) J. F. Watson, palma-rosa, Cymbopogon nardus (L.) Rendle, citronela, Elyonurus candidus (Trin.) Hack., capim-limão, Vetiveria zizanioides (L.) Nash, vetiver. Fepagro 11, 31p. (2003).

5) Hess, S. C.; Peres, M. T. L. P.; Batista, A. L.; Rodrigues, J. P.; Tiviroli, S. C.; Oliveira, LG. L.; Santos, C. W. C.; Fedel, L. E. S.; Crispim, S. M. A.; Smania Junior, A.; Smania, E. F. A.; Flach, A.; Pantaroto, S. Evaluation of seasonal changes in chemical composition and antibacterial activity of Elyonurus muticus (Sprengel)O. Kuntze (Gramineae). Quím. Nova 30, 370-373(2007).

6) Chagonda, L. S.; Makanda, C.; Chalchat, J. The essential oils of wild and cultivated Cymbopogon validus (Stapf) Stapf ex Burtt Davy and Elionurus muticus (Spreng.) Kunth from Zimbabwe. Flavr. Fragr. J. 15, 100-104 (2000).

7) Lee, S. O.; Choi, G. J.; Jang, K. S.; Lim, H. K.; Cho, K. Y.; Kim, J. C. Antifungal activity of five plant essential oils as fumigant against postharvest and soilborne plant pathogenic fungi. Plant Pathol. J. 23, 97-102 (2007).

8) Marandi, R. J.; Hassani, A.; Ghosta, Y.; Abdollahi, A.; Pirzad, A.; Sefidkon, F. Control of Penicillium expansum and Botrytis cinerea on pear with Thymus kotschyanus, Ocimum basilicum and Rosmarinus officinalis essential oils. J. Med. Plant Res. 5, 626- 
$634(2011)$.

9) Nguefack, J.; Tamgue, O.; Lekagne Dongmo, J. B.; Dakole, C. D.; Leth, V.; Vismer, H. F.; Amvam Zollo, P. H.; Nkengfack, A. E. Synergistic action between fractions of essential oils from Cymbopogon citratus, Ocimum gratissimum and Thymus vulgaris against Penicillium expansum. Food Control 23, 377-383(2012).

10) Agrios, G. N. Plant pathology. 5th ed. California: Academic Press, 2005. 948 p.

11) Tichelaar, G. M. Studies on the biology of Botrytis allii on Allium cepa. Neth. J. Plant Pathol. 73, 157160 (1967).

12) Rosslenbroich, H. J.; Stuebler, D. Botrytis cinerea history of chemical control and novel fungicides for its management. Crop Prot. 19, 557-561 (2000).

13) Williamson, B.; Tudzynski, B.; Tudzynski, P.; Vankan, J. L. Botrytis cinerea: the cause of grey mould disease. Molecular Plant Pathol. 8, 561-580 (2007).

14) Andersen, B.; Smedsgaard, J.; Frisvad, J. C. Penicillium expansum: consistent production of PAT, chaetoglobosins, and other secondary metabolites in culture and their natural occurrence in fruit products. J. Agr. Food Chem. 52, 2421-2428(2008).

15) Stefanazzi, N.; Stadlerb, T.; Ferreroa, A. Composition and toxic, repellent and feeding deterrent activity of essential oils against the stored-grain pests Tribolium castaneun (Coleoptera: tenebrionidae) and Sitophilus oryzae (Coleoptera: Curcuionidae). Pest Manage. Sci. 67, 639-646 (2010)

16) Kpoviessi, B. G. H. K.; Ladekan, E. Y.; Kpoviessi, D. S. S.; Gbaguidi, F.; Yehouenou, B.; Quetin-Leclercq, J.; Figueredo, G.; Moudachirou, M.; Accrombessi, G. C. Chemical variation of essential oil constituents of Ocimum gratissimum L. from Benin, and impact on antimicrobial properties and toxicity against Artemia salina Leach. Chem. Biodiversity 9, 139-150 (2012).

17) Solis, P. N.; Wright, C. W.; Anderson, M. M.; Gupta, M. P.; Phillipson, J. D. A microwell cytotoxicity assay using Artemia salina (brine shrimp). Planta Med. 26, 250-252 (1993).

18) McLaughlin, J. L.; Rogers, L. L.; Anderson, J. E. The use of biological assays to evaluate botanicals. Drug Inf. J. 32, 513-524 (1998).

19) Scramim, S.; Saito, M. L. Essential oil of Elyonurus muticus (Sprengel) O. Kuntze(Gramineae). J. Essent. Oil Res. 12, 298-300 (2000).

20) Füller, T. N.; Tessele, C.; Barros, I. B.I .; Barbosa-Neto, J. F. Phenotypical, phytochemical and molecular characterization of capim-carona[Elionurus muticus (Spreng.) Kuntze]populations. Braz. J. Plant Med. 12, 261-268(2010)

21) Cacciabue, M.; Gallucci, N.; Cordero, G. P.; Kolb, N.; Demo, M.; Sabini, L. Elionurus muticus from north of Argentina: evaluation of the antibacterial activity of three essential oil chemotypes. Biocell 29, 223 (2005).

22) Sabini, L. I.; Gabrielli, P. C.; Torres, C. V; Escobar, F. M.; Cacciabue, M.; Rovera, M.; Kolb, N. Study of the cytotoxic and antifungal activity of the essential oil of Elyonurus muticus against Candida spp. Mol. Med. Med. Chem. 11, 31-33(2006).

23) Santos, A. S.; Alves, S. M.; Baker, D.; Rocha Neto, O. Descrição de Sistemas e de Métodos de Extração de Óleos Essenciais e Determinação de Umidade de Biomassa em Laboratório. Comunicado Técnico MAPA 99, 1-7 (2004).

24) Adams, R. Identification of essential oil components by gas chromatography/quadrupole mass spectroscopy. Carol Stream, USA: Allured Publishing Corporation. (1995).

25) Babushok, V. I.; Zenkevich, I. G. Retention indices for most frequently reported essential oil compounds in GC. Chromatographia 69, 257-269 (2009).

26) R Development Core Team R: A language and environment for statistical computing. R Foundation for Statistical Computing, Vienna, Austria. ISBN 3-90005107-0, URL http://www.R-project.org. Accessed on 24 March 2013. (2008).

27) Ostrosky, E. A.; Mizumoto, M. K.; Lima, M. E. L.; Kaneko, T. M.; Nishikawa, S. O.; Freitas, B. R. Métodos para avaliação da atividade antimicrobiana e determinação da concentração mínima inibitória(CMI) de plantas medicinais. Braz. J. Pharmacognosy 18, 301307 (2008).

28) Reed, L. J.; Muench, H. A simple method of estimating fifty per cent end points. Am. J. Trop. Med. Hyg. 27, 493-497 (1938).

29) Mevy, J. P.; Bessiere, J. M.; Dherbomez, M.; Viano, J. Composition and some biological activities of the essential oils from an African pasture grass: Elionurus elegans Kunth. J. Agric. Food Chem. 50, 4240-4243 (2002).

30) Silou, T.; Loubaki, L.; Figueredo, G.; Chalchat, J. C. Study of essential oil composition of Elionurus hensii Schum from Congo. J. Essent. Oil Res. 18, 518520 (1993)

31) Alvarez-Castellanos, P. P.; Bishop C. D.; Pasqual-Villalobos M. J. Antifungal activity of the essential oil of flowerheads of garland chrysanthemum (Chrysanthemum coranarium) against agricultural pathogens. Phytochemistry 57, 99-102 (2001).

32) Edris, A. E., Farrag, E. S. Antifungal activity of peppermint and sweet basil essential oils and their major aroma constituents on some plant pathogenic fungi from the vapour phase. Nahrung/Food 47, 117-121 (2003).

33) Inouye, S., Tsuruoka, T., Watanabe, M., Takeo, K., Akao, M., Nishiyama, Y., Yamaguchi, H. Inhibitory effect of essential oils on apical growth of Aspergillus 
fumigatus by vapour contact. Mycoses 43, 17-23 (2000).

34) Espinel-Ingroff, A. In vitro activity of the new triazole Voriconazole (UK-109,496) against opportunistic filamentous and dimorphic fungi and common and emerging yeast pathogens. J. Clin. Microbiol. 36, 198-202 (1998).

35) Zabka, M.; Pavela, R.; Slezakova, L. Antifungal effect of Pimenta dioica essential oil against dangerous pathogenic and toxinogenic fungi. Ind. Crop. Prod. 30, 250-253 (2009).

36) Soylu, E. M.; Soylu, S. K. In vitro and in vivo antifungal activities of the essential oils of various plants against tomato grey mould disease agent Botrytis cinerea. Int. J. Food Microbiol. 143, 183-189 (2010).

37) Marandi, R .J.; Hassani, A.; Ghosta, Y.; Abdollahi, A.; Pirzad, A.; Sefidkon, F. Control of Penicillium expansum and Botrytis cinerea on pear with Thymus kotschyanus, Ocimum basilicum and Rosmarinus officinalis essential oils. J. Med. Plant. Res. 5, 626634 (2011).

38) Sousa, P. P. R. de.; Pereira, F. de O.; Lima, R. de S.; Lima, E. de O. Antifungal action of Cinnamomum zeylanicum Blume essential oil against Penicillium spp from environment air of a dry food industry. Int. Res. J. Microbiol. 2, 173-178(2011).

39) Tripathi, P.; Dubey, N. K.; Shukla, A. K. Use of some essential oils as post-harvest botanical fungicides in the management of grey mould of grapes caused by Botrytis cinerea. World J. Microbiol. Biotechnol. 24, 39-46 (2008).

40) Siripornvisal, S.; Rungprom, W.; Sawatdikarn, S. Antifungal activity of essential oils derived from some medicinal plants against grey mould(Botrytis cinerea). As. J. Food Ag-Ind. S229-S233 (2009).

41) Osório, G. T.; Oliveira, B. S.; Piero, R. M. di. Efeito de agentes fumigantes sobre o bolor azul e o mofo cinzento em frutos de maçã. Trop. Plant Pathol. 38, 063-067 (2013).

42) Tzortzakis, N. G.; Economakis, C. M. Antifungal activity of lemongrass (Cympopogon citratus L.) essential oil against key postharvest pathogens. Innov. Food Sci. Emerg. Technol. 8, 253-258(2007).
43) Ben-Yehoshua, S.; Rodov, V.; Jin, J.; Carmeli, S. Preformed and induced antifungal materials of citrus fruit in relation to the enhancement of decay resistance by heat and ultraviolet treatment. J. Agr. Food Chem. 40, 1217-1221 (1992).

44) Nguefack, J.; Tamgue, O.; Lekagne Dongmo, J. B.; Dakole, C. D.; Leth, V.; Vismer, H. F.; Amvam Zollo, P. H.; Nkengfack, A. E. Food preservative potential of essential oils and fractions from Cymbopogon citratus, Ocimum gratissimum and Thymus vulgaris against mycotoxigenic fungi. Int. J. Food Microbiol. 131, 151-156 (2009).

45) Linde, J. H.; Combrinck, S.; Regnier, T. J. C.; Virijevic, S. Chemical composition and antifungal activity of the essential oils of Lippia rehmannii from South Africa. S. Afr. J. Bot. 76, 37-42(2010).

46) Hossain, M. A.; Ismail, Z.; Rahman, A.; Kang, S. C. Chemical composition and anti-fungal properties of the essential oils and crude extracts of Orthosiphon stamineus Benth. Ind. Crop. Prod. 27, 328-334 (2008).

47) Isman, M. B.; Machial, C. M. Pesticides based on plant essential oils: from traditional practice to commercialization. Adv. Phytomedicine 3, 29-44(2006).

48) Wuriatmo, E. Application of citral to control postharvest diseases of oranges. 2011. 203f. Thesis School of Agriculture, Food and Wine, Faculty of Science, The University of Adelaide, Adelaide (2011).

49) Kofi, K.; Sanda, K.; Guyon, C.; Raynaud, C.; Chaumont, J. P; Nicod, L. In vitro cytotoxic activity of Cymbopogon citratus L. and Cymbopogon nardus L. essential oils from Togo. Bangladesh J. Pharmacol. 4, 29-34(2009).

50) Olivero-Verbel, J.; Güette-Fernandez, J.; Stashenko, E. Acute toxicity against Artemia franciscana of essential oils isolated from plants of the genus Lippia and Piper collected in Colombia. Bol. Latinoam. Caribe Plant. Med. Aromat. 8, 419-427(2009).

51) Carballo, J. L.; Zaira, L.; Hernández-Inda, Z. L.; Pérez, P.; García-Grávalos, M. D. A comparison between two brine shrimp assays to detect in vitro cytotoxicity in marine natural products. BMC Biotechnology 2, 1-5 (2002). 